\section{Jurnal Keuangan dan Perbankan \\ UNIVERSITY OF MERDEKA MALANG}

Article history:

Received: 2019-01-21

Revised: 2019-03-04

Accepted: 2019-04-02

Keywords:

Banking sector; BUKU; KMV-Merton

Model; Probability of default

JEL Classification: G21, G32, G33

Kata kunci:

Sektor perbankan; BUKU; Model

KMV-Merton; Probabilitas

kegagalan

\title{
Probability of default as the early warning system for the Indonesian banking sector
}

\author{
Ari Christianti \\ Department of Management, Faculty of Business, Duta Wacana Christian University \\ Jl. Dr. Wahidin S. No.05-25 Yogyakarta, 55224, Indonesia
}

\begin{abstract}
Early warning system for banks is used to predict default risk. This research is to test the probability of defaults with the probability of default in the real condition of banks. The probability of default risk is measured by KMV-Merton Model and the probability of default in the real condition of banks is bank's performance based on whether there are bank's actions that cause changes in the bank's financial statements report. This study using banks listed in the Indonesian Stock Exchange (IDX) from 2010-2015. This study analysis probability of default with financial condition based from 4 commercial bank categories and BUKU (Commercial Bank Based on Business Activities) categories. The results of this study are the probability of default with Merton model give a strong signal against the default of bank for one bank only but for banks in BUKU 4 give a strong signal that banks in this category do not default. Since for other banks and for other BUKU categories do not represent the real condition from the probability of default. It can be concluded that the Merton model is not generated sufficient enough model to predict the probability of default since it assumes that the market is in under efficient condition, and it just considers firmspecific risk.
\end{abstract}

\section{Abstrak}

Sistem peringatan dini bagi bank digunakan untuk memprediksi risiko kegagalan pada bank. Penelitian ini menguji probabilitas kebangkrutan bank dengan kondisi riil bank. Probabilitas kebangkrutan diukur dengan model KMV-Merton dan kondisi riil perusahaaan menggunakan kinerja bank berdasarkan apakah ada tindakan bank yang memengaruhi perubahan laporan keuangan. Menggunakan sampel bank-bank yang terdaftar di Bursa Efek Indonesia dari tahun 2010-2015. Penelitian ini menganalisis probabilitas kebangkrutan dan kinerja keuangan berdasarkan 4 kategori bank umum dan kategori BUKU (Bank Umum berdasarkan Kegiatan Usaha). Hasil penelitian menunjukkan bahwa probabilitas kebangkrutan dengan model Merton memberikan sinyal yang kuat terhadap kegagalan bank hanya pada satu bank saja tetapi untuk bank-bank yang masuk dalam BUKU 4 memberikan sinyal yang kuat bahwa bank-bank BUKU 4 tidak gagal. Bank-bank lain dan bank-bank kategori BUKU 1, 2 dan 3 walaupun memiliki probabilitas kegagalan yang tinggi tapi tidak menunjukkan adanya kondisi kegagalan secara riil. Dapat diambil kesimpulan bahwa model Merton tidak menghasilkan model yang cukup untuk memprediksi probabilitas kegagalan karena model ini mengasumsikan bahwa pasar berada dalam kondisi efisien, dan hanya mempertimbangkan risiko spesifik perusahaan saja.

How to Cite: Christianti, A. (2019). Probability of default as the early warning system for the Indonesian banking sector. Jurnal Keuangan dan Perbankan, 23(2), 283-299. https:// doi.org/10.26905/jkdp.v23i2.2856 


\section{Jurnal Keuangan dan Perbankan}

Volume 23, Issue 2, April 2019: 283-299

\section{Introduction}

Banks as the intermediation institutions have to conduct prudential principles when running their activities. These principles are required because banks encounter risks when they manage their assets and their liabilities. How serious the risks depend on the banks' ability in managing their risks.

Activities of managing credits are one of the very important activities which can improve the role of banks as intermediation institutions in encouraging economic growth. Furthermore, bad credit management will cause a credit default and will influence the soundness of a bank's operations. Regarding this, Jorion (2009) explained that the main cause of credit risk increases is that many debtors fail to pay-off their obligations. Actually, if credit risk is getting higher, it will potentially decrease the capital quickly and will drive to bank default. Therefore, banks need an Early Warning System (EWS) as an early warning for banks in making decisions and policies to decrease default risk.

Many studies are doing to find out the default risk measured, several analytical tools exist to measure the default risk of a company. Pioneered by the Altman model (1968), presented Multiple Discriminant Analysis (MDA) to identify distress prediction which recently Altman Z-Score was futher test by Rim \& Roy (2014). Ohlson model (1980 with logit analysis proposed to overcome the Altman model, also have studied and improved this model by Sun et al. (2014); Jones; Johnstone, \& Wilson (2015; 2017). Next, Zmijewski model (1984) employed probit analysis which futher research including $\mathrm{Wu}$ et al. (2010) and Kleinert (2014). Furthermore, the Merton model (1974) is known as market-based information. Merton model has been perceived as a forward-looking model that could predict the probability of default. Studies on the Merton Model is superior and favorable model than accounting-based information model has been carried out among them Das Hanouna, \& Sarin (2009); Tanthanongsakkun, Pitt, \& Treepongkaruna (2009); Li \& Miu (2010);
Duan \& Ren (2011); Liang (2012); Yeh, Lin, \& Hsu (2012); Mansi, Maxwell, \& Zhang (2012); Bellalah Zouari, \& Levyne (2016); and Yusof \& Jaffar (2017).

In relation to this, Löffler \& Posch (2011) explained 2 approaches were used to build credit risk modeling, namely reduced-form modeling and Structural Modelling. In the first model explained, that event of default occurred as it one or more events effected in borrower's value of assets. This model didn't have an explicit model to explain the relation between default events and the value of assets. It assumed that time of default occurred inaccessible default time. In the second model, a company was assumed default when the value of assets is under a certain critical limit at maturity period. This model begins from option modeling by Black \& Scholes (1973) and expanded by Merton (1974) who built default risk by modified Black Scholes Model. Hence, it called the Black-Scholes-Merton Model (BSM) referred to the Merton Model. Furthermore, KMV (Kealhofer, McQuown, \& Vasicek), a software and consulting company in the United States developed the model, known as KMV Merton Model.

Based on the explanations above, this research aims to measure and analyze the probability of default (PD) in the banking sector in Indonesia Stock Exchange with the Merton Model. Yeh, Lin, \& Hsu (2012) stated that KMV Merton model or marketbased information provides valuable information in credit rating predictions. Mansi, Maxwell, \& Zhang (2012) stated that the Merton distance to default model is superior to Altman's Z-Score and Ohlson's O-Score (accounting based models). This study will analysis the cause of the high PD and. This study will analyze the cause of the high PD and try to investigate the consistency between PDs from the Merton Model with the probability of default in the real condition of banks. So, this research contributed to management and investor by providing a new tool that assists them in developing an early warning system to predict the potential problems in the Indonesian banking system. The early warn- 
ing system is necessary because the complexity of banking system network such as the potential of domino effect (systemic risk) that arises when there are one or more banks in the system has a failure of operations and caused a very large cost due to the bankruptcy of a bank.

Financial Services Authority regulations itself already has an Indonesian banking health rating system that is using a CAMEL rating system that can be used as an early warning system. However, this institution unable to disclose all details to the general public about the health condition (CAMEL rating system score) achieved by individual banks because of banking secrecy clause in banking law. In addition, this institution does not publish CAMEL rating system scores with the fact that there is no effective deposit insurance program in Indonesia yet and avoiding the panic of customers in knowing the bank where he or she saves has a low health score.

There have been many researchers conducted using the Merton Model. Li \& Miu (2010), for example which investigated listed firms in the Fortune 500 with over a B-rating during 1996-2006 found that the distance-to-default (DD) from the Merton Model is statistically significant in explaining the observed default events. Futhermore, Das Hanouna, \& Sarin (2009), used the hybrid model (Merton Model and Accounting Model) stated that the hybrid model has better explanatory power for CDS spreads and in pricing financial distress than either of the two models. In line with that, Bellalah Zouari, \& Levyne (2016) used the market and the values derived from financial statements. The result was the KMV Merton model contribute significantly in explaining default risk when included in a hybrid model with accounting variables. Default risk was also analyzed by Tsesmelidakis \& Merton (2013) and Acharya, Deniz, \& Warburton (2016). These studies investigated the value of implicit (too-big-to-fail) government guarantees. They used distance to de- fault from Merton Model as a primary risk measure.

In Asia, there have been researches conducted using KMV-Merton Model. Duan \& Ren (2011), for example identified credit risk from thirty companies in energy sector in Chinese with the time period of 2001 to 2010. The result indicated that the KMV-Merton Model had the ability to identify credit risk in the energy industry of China. Liang (2012) also used the Merton-KMV Model for Chinese listed companies during the period of 2000 to 2010. The results revealed that KMV-Merton was a significant model to predict default in the Chinese market. Futhermore Yeh, Lin, \& Hsu (2012) indicated that KMV Merton model or market-based information provides valuable information in credit rating predictions in Taiwanese high-technology companies. Yusof \& Jaffar (2017) also used KMV Merton to forecast the probability of default of Malaysian Airlines System Berhad. The result showed that high probability default were equivalent to the financial loses faced by MAS from 20112013. Therefore, KMV Merton Model is a valid model to forecast the probability of default in current and future default.

The purpose of this research is comparing the probability of defaults with the probability of default in the real condition of banks. The probability of default risk is measured by KMV-Merton Model and the probability of default in the real condition of banks is the bank's performance based on the bank's financial statements report including corporate actions that followed it.

\section{Method, Data, and Analysis}

The sample of this research consists of 24 commercial banks with purposive sampling from 20102015 periods. The following Table 1 represents 24 commercial banks used as a sample. 


\section{Jurnal Keuangan dan Perbankan}

Volume 23, Issue 2, April 2019: 283-299

In this study, banks are categorized in 4 groups such as (1) government bank, (2) non-government bank with foreign exchange transactions, (3) non-government bank with no exchange transactions, and (4) mixed bank. Government bank is a bank which most of the shareholder is owned by the government. There are 4 government banks in Indonesia such as BMRI, BBRI, BBNI, and BBTN. The second category is a non-government bank with foreign exchange transactions which is owned by a private and non-foreign person. This bank's category has extra activities such as overseas transactions and foreign exchange. There are 16 banks that include in this category. Next bank's category is a non-government bank with no exchange transactions. Banks in this category are not permitted to take activities to foreign exchange. There are 2 banks in this category such as BTPN and BVIC. The last categories are a mixed bank. There are 2 mixed banks in Indonesia such as BACA and MCOR. In this study, these groups are used to investigate whether the PD's values are different among groups.

In addition, this study also analyzed PD with banks' performance based on BUKU (Based on Business Activities) as a comparison. BUKU is a grouping of banks based on core capital (tier 1) which is regulated by Bank Indonesia (BI) in BI Reg. 14/26/ 2012. Based on core capital, Bank are grouped into 4 groups consist of BUKU 1: Banks with core capital of less than 1 Trillion rupiah; BUKU 2: Banks with core capital of 1 Trillion rupiah up to less than 5 Trillion rupiah; BUKU 3: Banks with core capital of 5 Trillion rupiah up to less than 30 Trillion rupiah; and BUKU 4: Banks with core capital at least 30 Trillion rupiah.

The technical analysis of the data with the sequence of the research explained the steps from the purpose of the research. It started with collecting data from the financial report, IDX (Indonesia Stock Exchange) statistics, interest rate, and closing price from banks listed in IDX. Next step, this study calculates the PD with KMV Merton Model and comparing them with real financial performance included an event that might be following the real of the bank's probability of default condition. This research tried to analyze banks which have PD's score above 20 percent since this indicated Corporate rated D according to Bond-rating based on probability of default value by Moody's (Jorion, 2009). Corporate with $\mathrm{D}$ rating is in default on all of their long-term debt obligations.

\section{The measurement of the probability of default}

This research will focus on the structural approach to measure the probability of default. This approach is the development of Black Scholes (1973) and Merton (1974). The structural model to mea-

Table 1. 24 Commercial banks as a sample of the study

\begin{tabular}{ll}
\hline \multicolumn{1}{c}{ Name of bank } & \multicolumn{1}{c}{ Name of bank } \\
\hline Bank Rakyat Indonesia Agro Niaga (AGRO) & Bank Maybank Indonesia (BNII) \\
Bank MNC Internasional (BABP) & Bank Permata (BNLI) \\
Bank Capital Indonesia (BACA) & Bank of India Indonesia (BSWD) \\
Bank Central Asia (BBCA) & Bank Tabungan Pensiunan Nasional (BTPN) \\
Bank Bukopin (BBKP) & Bank Victoria International (BVIC) \\
Bank Negara Indonesia (BBNI) & Bank Artha Graha International (INPC) \\
Bank Rakyat Indonesia (BBRI) & Bank Mayapada International (MAYA) \\
Bank Tabungan Negara (BBTN) & Bank Windu Kentjana International (MCOR) \\
Bank Danamon Indonesia (BDMN) & Bank Mega (MEGA) \\
Bank Mandiri (BMRI) & Bank OCBC NISP (NISP) \\
Bank Bumi Arta (BNBA) & Bank Pan Indonesia (PNBN) \\
Bank CIMB Niaga (BNGA) & Bank Woori Saudara Indonesia 1906 (SDRA) \\
\hline
\end{tabular}


sure default risk is still considered an important tool in assessing company default. Tudella \& Young (2003) applied the Merton model to corporations in the UK and found that the probability of default (PD) with a structural model is quite good explaining the probability of failure of a company. In this study, PD is calculated using the Merton model with an iterative method whose formulation is as follows: (Löffler \& Posch, 2011):

$$
\begin{gathered}
D D=\frac{\ln A_{t}+\left(\mu-\sigma^{2} / 2\right)(T-t)-\ln L}{\sigma \sqrt{(T}-t)} \\
P D=\operatorname{Prob}(\text { Default })=\theta[-D D]
\end{gathered}
$$

With DD is Distance to Default, $A_{t}$ is the market value of assets, $\mu$ is drift rate, $\sigma$ is the volatility of assets, $\mathrm{L}$ is the book value of liquidity, and T-t is an assumption the bank's debt assumption will mature in the next year so that $\mathrm{T}-\mathrm{t}=1$.

The most important thing about the Merton Model this iteration method is how to determine the asset value and volatility of an unknown asset. Asset value is calculated by equating the market value of assets with the sum of the equity value and debt value carried out with 265 iterations (in accordance with the stock trading days in a year). Meanwhile, the asset volatility value can be calculated from the standard deviation of the log return (the market value of assets obtained from the iteration process)

\section{Financial performance}

Asset, liability, equity, liability to assets, NPL (Non-Performing Loan), Operational Cost divided to Operating Income, ROA (Return on Assets), ROE (Return on Equity), are used to analyze the movements of PDs and bond rating from banks. Asset and liabilities are used in this section because default occurs if the value of the assets falls below with the firm's liabilities (Merton, 1974) and could be affected by equity. NPL is one of credit risk proxy. It calculated by the sum of borrowed upon which the debtors have not made their scheduled payments for at least 90 days divided to a total of credit. OEOI is an efficiency ratio calculated operational cost divided into operational income. ROA is a profitability ratio that measures the effectiveness of corporate assets in generating profits. Furthermore, ROE measures the ability of corporate equities in generating profits. In line in that, this study uses all of them to investigate whether the PD's values are different among groups based on those values. The quantitative information consists of NPL, OEOI, $\mathrm{ROE}$, and ROA are explain in this section.

NPL shows the bank's management capability to manage non-performing loans. The higher this ratio will cause the worse of the credit quality. Loans, in this case, are credits granted to third parties excluding credits to other banks. Non-performing loans are loans with substandard quality, doubtful, and loss. The higher this ratio, the more it will be the worse the quality of bank credit that causes the amount of credit the bigger the problem that can have an impact on the company's financial condition. This ratio can be formulated as follows,

$N P L=\frac{\text { Non }- \text { Performing Loan }}{\text { Total Loans }}$

Operating Expenses Operating Income (OEOI) is often called the efficiency ratio which used to measure the ability of bank management in controlling operational costs to operating income. The smaller of this ratio means the more efficient operational costs incurred by the bank concerned. It means that the possibility of a bank in the troubled condition is getting smaller. So that a bank can have a small OEOI ratio, the bank must increase operating income or by reducing the operational costs incurred. OEOI value certainly affects the condition of financial difficulties in a bank. This ratio is formulated as follows,

OEOI $=\frac{\text { Operating Cost }}{\text { Operating Income }} \times 100$ 


\section{Jurnal Keuangan dan Perbankan}

Volume 23, Issue 2, April 2019: 283-299

ROE is used to measure the performance of bank management in managing the available capital to generate profit after tax. The greater the ROE, the greater the level of profit achieved by the bank so the possibility of a bank in troubled conditions is getting smaller. This ratio is formulated as follows,

$R O E=\frac{\text { Net Income }}{\text { Equity }}$

ROA used to measure the ability of bank management in obtaining profit (profit before tax) from total assets. The greater the ROA, the greater the level of profit achieved so the possibility of a bank in the troubled condition is getting smaller. This ratio can be formulated as follows,

$R O A=\frac{\text { Net Income }}{\text { Total Assets }}$

\section{Results}

The objective of this analysis is to prove whether the probability of default from the Merton model is consistent with the probability of default in the real condition of banks. In this section, this research will explain about the comparison assets, liability, and liabilities to assets, NPL, OEOI, ROA, ROE, and the probability of default from 4 bank categories as an introduction to the analysis.

\section{Assets description analysis}

Assets are resources used by banks to operate their activities. Assets of banks consist of 3 investment namely assets from the capital market, interbank money market, and holding loans. Table 4 shows assets that owned by 4 categories of banks

Table 2. Assets for 4 categories of banks

\begin{tabular}{crrr}
\hline Bank & \multicolumn{3}{c}{ Assets (billion rupiahs) } \\
\cline { 2 - 4 } Categories & \multicolumn{1}{c}{ Average } & \multicolumn{1}{c}{ Min } & \multicolumn{1}{c}{ Max } \\
\hline 1 & $449,047.86$ & $68,385.54$ & $910,063.41$ \\
2 & $95,551.24$ & $1,570.33$ & $594,372.77$ \\
3 & $38,852.52$ & $10,304.85$ & $81,039.66$ \\
4 & $7,365.77$ & $4,354.46$ & $12,159.20$ \\
\hline
\end{tabular}

Based on Table 2, it shows that banks with the highest assets of others are the bank $1^{\text {st }}$ category. It is a government's bank with average assets is $449,047.86$ billion rupiahs. BMRI is a government bank which has the highest assets of others with the value of assets nearly 1,000 trillion rupiahs. Furthermore, a bank in the $4^{\text {th }}$ category has the smallest average assets of other categories with just 7,365.77 billion rupiahs. Actually, from individual data, the smallest assets are had by the bank with the $2^{\text {nd }}$ category (the non-government bank with foreign exchange transactions) is BSWD. BSWD is small retail bank that shares are listed in the Indonesia Stock Exchange in 2002.

It can be concluded that the government's banks have dominant assets in banking industries in Indonesia. BMRI has the highest assets with 910,063.41 billion rupiahs, followed by BBRI which assets was $878,426.31$ billion rupiahs of assets in 2015. Next, BBNI also had assets amount 508,595.29 billion rupiahs and followed by BBTN with had assets amount 171,807.59 billion rupiahs.

Table 3. Assets for BUKU categories

\begin{tabular}{crrr}
\hline BUKU & \multicolumn{3}{c}{ Assets (billion rupiahs) } \\
\cline { 2 - 4 } Categories & \multicolumn{1}{c}{ Average } & \multicolumn{1}{c}{ Min } & \multicolumn{1}{c}{ Max } \\
\hline 1 & $6,658.38$ & $2,540.74$ & $12,159.20$ \\
2 & $19,340.51$ & $3,483.52$ & $65,689.83$ \\
3 & $133,969.02$ & $59,090.13$ & $238,849.25$ \\
4 & $607,684.08$ & $333,303.51$ & $910,063.41$ \\
\hline
\end{tabular}

Based on BUKU categories, Table 3 shows that banks with the highest assets of others are banks in BUKU 4. They are banks with average assets is $607,684.08$ billion rupiahs. Banks in BUKU 4 consist of BMRI, BBCA, BBRI, and BBNI. Furthermore, banks in BUKU 1 have the smallest average assets of others with just 6,658.38 billion rupiahs. Banks in BUKU 1 consist of AGRO, BABP, BACA, BSWD, MCOR, and SDRA. In 2013, SDRA migrated to BUKU 2 than it followed by BABP and MCOR which also migrated from BUKU 1 to BUKU 2 in 2014. It can be concluded that the government's banks have domi- 
nant assets in banking industries in Indonesia. BBCA is the only a private bank included in BUKU 4.

\section{Liabilities description analysis}

Liabilities is the bank's financial debt or obligations that arise during its business operations. Liabilities are the sources of fund securities owned by the bank which obtained from the capital market in the form of bond, the second is interbank money market in the form of call money, and the third is liquidity credit from central bank as an example is bank borrow to central bank, and the last is loan holding from depositors. Table 4 shows the liabilities owned by 4 categories of banks.

Table 4. Liabilities for 4 categories of banks

\begin{tabular}{crrr}
\hline Bank & \multicolumn{3}{c}{ Liabilities (billion rupiahs) } \\
\cline { 2 - 4 } Categories & \multicolumn{1}{c}{ Average } & \multicolumn{1}{c}{ Min } & \multicolumn{1}{c}{ Max } \\
\hline 1 & $385,543.85$ & $61,938.26$ & $765,299.13$ \\
2 & $83,765.22$ & $1,251.62$ & $501,945.42$ \\
3 & $33,023.72$ & $9,562.16$ & $64,053.23$ \\
4 & $6,511.73$ & $3,833.04$ & $11,105.78$ \\
\hline
\end{tabular}

Table 4 shows that banks with the highest average liabilities of others are bank category 1 . It is a government's bank with average liabilities is $385,543.85$ billion rupiahs. BBRI is a government bank which has the highest liability of others with the value of the liability is 765,299.13 trillion rupiahs. Furthermore, bank category 4 has the smallest average liability of other categories with just $6,511.73$ billion rupiahs. The smallest liability of bank having individually is had by the bank with category 2 (non- government bank with foreign exchange transactions) is BSWD with amount 1,251.62 billion rupiahs.

Government's banks have a dominant liability in banking industries in Indonesia. BBRI has the highest liability with 765,299.13 billion rupiahs, followed by BMRI which liability was 736,198.62 billion rupiahs in 2015. Next, BBNI also had liability amount 412,727.68 billion rupiahs and followed by BBTN with had assets liability $157,947.49$ billion rupiahs.

Table 5. Liabilities for BUKU Categories

\begin{tabular}{crrr}
\hline BUKU & \multicolumn{3}{c}{ Liabilities (billion rupiahs) } \\
\cline { 2 - 4 } Categories & \multicolumn{1}{c}{ Average } & \multicolumn{1}{c}{ Min } & \multicolumn{1}{c}{ Max } \\
\hline 1 & $5,872.04$ & $2,166.97$ & $11,105.78$ \\
2 & $17,118.29$ & $2,961.01$ & $60,693.09$ \\
3 & $117.681,68$ & $51,356.21$ & $210,169.87$ \\
4 & $516,871.89$ & $289,778.22$ & $765,299.13$ \\
\hline
\end{tabular}

Table 5 shows that banks with the highest average liabilities of others are bank BUKU 4. They are banks with average liabilities is $516,871.89$ billion rupiahs. Furthermore, banks BUKU 1 have the smallest average liability of other categories with just 5,872.04 billion rupiahs. Banks BUKU 4 is dominated by a government bank. Although government banks contribute the largest debt. However, third party funds managed by this bank are used for lending to drive the economy. In addition, the performance of government banks in BUKU 4 is good.

\section{Liabilities to assets description analysis}

Liabilities to assets ratio is used in this study to analyze how banks in using debt in their operational activity compare with their assets. It indicates the proportion of a company's assets that are being financed with debt, rather than equity. A ratio greater than 1 shows that a considerable proportion of assets are being funded with debt, while a low ratio indicates that the bulk of asset funding is coming from equity. Table 6 shows liabilities to assets ratio that owned by 4 categories of banks

Table 6. Liabilities to assets for 4 categories of banks

\begin{tabular}{cccc}
\hline Bank & \multicolumn{3}{c}{ Liabilities to Assets (\%) } \\
\cline { 2 - 4 } Categories & Average & Min & Max \\
\hline 1 & 87.27 & 80.90 & 91.93 \\
2 & 88.00 & 76.24 & 93.98 \\
3 & 87.05 & 79.04 & 92.79 \\
4 & 88.28 & 85.99 & 91.36 \\
\hline
\end{tabular}


Based on Table 6, it shows that banks that have the highest average of liabilities to assets ratio are bank category $4^{\text {th }}$. It is a mixed bank category with average liabilities to assets ratio is 88.28 percent. Furthermore, a bank which has the highest liabilities to assets ratio of all banks with the value of liabilities to assets ratio is 93.98 percent is INPC (the non-government bank with foreign exchange transactions). Bank category $3^{\text {rd }}$ has the smallest average liabilities to assets ratio of other categories with 87.05 percent. But, the smallest liabilities to assets ratio is had by the bank with category $2^{\text {nd }}$ (nongovernment bank with foreign exchange transactions) is SDRA with 76.24 percent.

All of the banks have liabilities to assets ratio smaller than 1. It shows that banks in Indonesia especially that listed in Indonesia Stock Exchange indicates the proportion of a company's assets that are being financed with debt, rather than equity.

Table 7. Liabilities to assets for BUKU categories

\begin{tabular}{cccc}
\hline BUKU & \multicolumn{3}{c}{ Liabilities to Assets (\%) } \\
\cline { 2 - 4 } Categories & Average & Min & Max \\
\hline 1 & 87.85 & 81.69 & 92.94 \\
2 & 87.40 & 76.24 & 92.98 \\
3 & 87.86 & 79.04 & 92.01 \\
4 & 85.30 & 80.90 & 88.23 \\
\hline
\end{tabular}

Based on Table 7, it shows that banks that have the highest average of liabilities to assets ratio are banks in BUKU 3 with 87.86 percent. Banks in this category have a debt to asset ratio with a range between 90-92 percent consisting of BBTN, BNII, BNLI, MEGA, and BBKP. In 2013, BBKP migrated from BUKU 2 to BUKU 3. Next, Banks BUKU 4 has the smallest average liabilities to assets ratio of other categories with the ratio is 85.30 percent.

\section{NPL description analysis}

NPL non-performing loans are key indicators for assessing bank performance. This ratio shows the bank's management capability to manage non- performing loans. The higher this ratio will cause the worse of the credit quality. Bank of Indonesia as the central bank has set maximum NPL for a bank is 5 percent. Table 8 shows assets owned by 4 categories of banks.

Table 8. NPL for 4 categories of banks

\begin{tabular}{cccc}
\hline Bank & \multicolumn{3}{c}{ NPL (\%) } \\
\cline { 2 - 4 } Categories & Average & Min & Max \\
\hline 1 & 2.63 & 1.55 & 4.30 \\
2 & 2.37 & 0.14 & 8.90 \\
3 & 1.91 & 0.58 & 5.07 \\
4 & 1.51 & 0.34 & 2.71 \\
\hline
\end{tabular}

Based on Table 8, it shows that all of the bank's categories have NPL under 5 percent. It means almost banks have good performance in managing loans. But individually, there are some banks that have NPL above 5percent. They are AGRO, BABP, and BSWD. In 2010, AGRO had NPL 8.82 percent in 2010, but in the following year AGRO able to reduce its NPL below 5 percent to 3.55 percent in 2010 . It's different from NPL with BABP from 2011 to 2012 was above 5 percent, 6.25 percent in 2011 and 5.78 percent in 2012. This condition was still consistent in 2014, its NPL 5.88 percent. As in the following year, BABP able to lower its NPL below 5 percent to 2.97 percent in 2015. Bank with the highest NPL individually is BSWD with 8.90 percent in 2015.

It can be concluded that average NPL from all categories banks are lower 5 percent. It means that the bank's management is able to manage its non-performing loans. Even though, there some banks with NPL above 5 percent, but they able to reduce their NPL to be 5 percent or under 5 percent in the following year, included BSWD.

Table 9. NPL for BUKU categories

\begin{tabular}{cccc}
\hline BUKU & \multicolumn{3}{c}{ NPL (\%) } \\
\cline { 2 - 4 } Categories & Average & Min & Max \\
\hline 1 & 2.45 & 0.14 & 8.90 \\
2 & 2.14 & 0.21 & 5.88 \\
3 & 2.20 & 0.58 & 4.09 \\
4 & 1.64 & 0.38 & 2.80 \\
\hline
\end{tabular}


Table 9 shows that banks that have the highest average of NPL are banks BUKU 1 with 2.45 percent. Banks BUKU 1 which have NPL above 5 percent are BABP and BSWD. Next, banks BUKU 4 has the smallest average NPL of other categories with 1.64 percent. It can be concluded that average NPL from banks in BUKU 3 and banks in BUKU 4 is lower than 5 percent. It means that the bank's management is able to manage its non-performing loans.

\section{OEOI description analysis}

OEOI is the efficiency ratio which used to measure the ability of bank management in controlling operational costs to operating income. Table 10 shows assets owned by 4 categories of banks.

Table 10. OEOI for 4 categories of banks

\begin{tabular}{cccc}
\hline Bank & \multicolumn{3}{c}{ OEOI (\%) } \\
\cline { 2 - 4 } Categories & Average & Min & Max \\
\hline 1 & 71.62 & 59.93 & 88.97 \\
2 & 85.27 & 56.04 & 235.20 \\
3 & 81.75 & 74.03 & 93.89 \\
4 & 89.22 & 81.74 & 93.19 \\
\hline
\end{tabular}

Based on Table 10, it shows that banks with the highest OEOI of others are a bank in the $2^{\text {nd }}$ category. It was a non-government bank with foreign exchange transactions with OEOI amount was 235.20 percent. BSWD is a bank which had the highest OEOI in 2014. Individually, there are 2 banks that have OEOI above 100 percent. They are BABP and BSWD. OEOI from BABP in 2011 was 114.63 percent, 107.77 percent in 2013 and 108.54 percent in 2014. Since in the following year BABP able lower its OEOI to 98.97 percent in 2015. Bank with the highest OEOI is BSWD with 235.20 percent in 2014 and 110.20 percent in 2015.

It can be concluded that the government's banks have the smallest OEOI than the others. It means that the government's banks are more able to control their operational costs to operating income. The most efficient banks are BBRI that had the lowest OEOI ratio with amount 59.93-70.86 percent during 2010-2015.

Table 11. OEOI for BUKU categories

\begin{tabular}{cccc}
\hline BUKU & \multicolumn{3}{c}{ OEOI (\%) } \\
\cline { 2 - 4 } Categories & Average & Min & Max \\
\hline 1 & 96.62 & 69.09 & 235.20 \\
2 & 86.26 & 56.04 & 108.54 \\
3 & 83.21 & 71.70 & 98.90 \\
4 & 65.49 & 59.93 & 75.50 \\
\hline
\end{tabular}

Based on Table 11, it shows that banks with the highest average of OEOI of others are banks in BUKU 1 with OEOI is 96.62 percent. Furthermore, banks in BUKU 4 have the smallest average OEOI of other categories with 65.49 percent. It can be concluded that banks in BUKU 4 are more able to control their operational costs to operating income. The most efficient banks are BBRI that had the lowest OEOI ratio with amount 59.93-70.86 percent during 2010-2015.

\section{ROA description analysis}

This ratio is used to measure the ability of bank management in obtaining profit (profit before tax) from total assets. Table 12 shows assets that owned by 4 categories of banks

Table 12. ROA for 4 categories of banks

\begin{tabular}{cccc}
\hline Bank & \multicolumn{3}{c}{ ROA (\%) } \\
\cline { 2 - 4 } Categories & Average & Min & Max \\
\hline 1 & 3.25 & 1.14 & 5.15 \\
2 & 1.85 & -1.64 & 3.90 \\
3 & 2.85 & 0.65 & 4.70 \\
4 & 1.22 & 0.74 & 2.04 \\
\hline
\end{tabular}

Based on Table 12, it shows that banks with the highest average of ROA are bank category $1^{\text {st }}$. It is a government's bank with average ROA is 3.25 . The lowest average ROA is 1.22 , its banks in the $4^{\text {th }}$ category. But individually, there are some banks that have negative ROA. They are BABP and BSWD. ROA from BABP in 2011 was -1.64, it was the low- 


\section{Jurnal Keuangan dan Perbankan}

Volume 23, Issue 2, April 2019: 283-299

est ROA of other banks. In 2014-2015, BABP also had a negative ROA. They were -0.93 in 2014 and 0.83 in 2015. BSWD ever had a negative ROA in 2014 was -0.77 .

It can be concluded that the government's banks have the highest ROA than the others. It means that the government's banks are more able to manage assets to obtain profit. The best performance bank that had the highest ROA is BBRI with amount 4.19-5.15 during 2010-2015.

Table 13. ROA for BUKU Categories

\begin{tabular}{cccc}
\hline BUKU & \multicolumn{3}{c}{ ROA (\%) } \\
\cline { 2 - 4 } Categories & Average & Min & Max \\
\hline 1 & 1.58 & -0.93 & 3.80 \\
2 & 1.46 & -0.82 & 2.81 \\
3 & 1.96 & 0.20 & 4.70 \\
4 & 3.78 & 2.60 & 5.15 \\
\hline
\end{tabular}

Based on Table 13, it shows that banks with the highest average of ROA are banks in BUKU 4 . The lowest average ROA is 1.46 percent, are banks in BUKU 2. Banks in BUKU 1 and banks in BUKU 2 have negative ROA at the minimum value. It can be concluded that banks in BUKU 4 have more able to manage assets to obtain profit.

\section{ROE description analysis}

This ratio is used to measure the performance of bank management in managing the available capital to generate profit after tax. Table 14 shows assets that owned by 4 categories of banks

Table 14. ROE for 4 Categories of Banks

\begin{tabular}{crrc}
\hline Bank & \multicolumn{3}{c}{ ROE (\%) } \\
\cline { 2 - 4 } Categories & Average & Min & Max \\
\hline 1 & 25.27 & 10.95 & 43.83 \\
2 & 13.53 & -18.96 & 33.50 \\
3 & 20.37 & 6.73 & 36.40 \\
4 & 8.38 & 5.11 & 15.91 \\
\hline
\end{tabular}

Based on Table 14, it shows that banks with the highest average of $\mathrm{ROE}$ are bank category 1 . It is a government's bank with average ROE is 25.27 percent. The lowest average ROE is 8.38 percent, its banks in category 4 . But individually, there are some banks that have negative ROE. They are BABP and BSWD. ROE from BABP in 2011 was -18.96 percent, it was the lowest ROE of other banks. In 2014-2015, BABP also had negative ROE. They were -16.28 percent in 2014 and -6.69 percent in 2015. BSWD ever had negative ROA in 2014 that was -4.50 percent.

It can be concluded that the government's banks have the highest ROE than the others. It means that the government's banks are more able to manage equity to obtain profit. Because of the greater the ROE, the greater the level of profit achieved. The best performance bank that had the highest ROE is with the amount of $29.89-43.83$ percent during 2010-2015.

Table 15. ROE for BUKU Categories

\begin{tabular}{crrr}
\hline BUKU & \multicolumn{3}{c}{ ROE (\%) } \\
\cline { 2 - 4 } Categories & Average & Min & Max \\
\hline 1 & 9.89 & -16.28 & 27.44 \\
2 & 11.90 & -6.69 & 25.87 \\
3 & 13.88 & 1.55 & 27.44 \\
4 & 26.66 & 17.20 & 38.66 \\
\hline
\end{tabular}

Based on 15, it shows that banks with the highest average of ROE are banks in BUKU 4. The lowest average ROE are banks in BUKU 1. Banks in BUKU 1 and banks in BUKU 2 have negative ROE at the minimum value. Therefore, banks BUKU 4 are more able to manage equity to obtain profit. Because of the greater the ROE, the greater the level of profit achieved.

\section{Probability of Default description analysis for $1^{\text {st }}$ category}

A default probability is the degree of likelihood that the borrower of a loan or debt will not be able to make the necessary scheduled repayments. Table 16 shows assets that owned by 4 categories of banks 
Based on Table 16, it shows that banks with the highest PD of others in bank category lare BBTN. It is a government's bank with the highest PD is 47.57 percent. BBTN is a government bank that has which given the task to succeeding the one million home program from the government. BBTN recorded that loan had been growth to 139 trillion rupiahs in 2015. This achievement grew by 19.88 percent during 2015 compared to 115.9 trillion in 2014. The housing loan portion has contributed 89.90 percent composition in 2015. During that period, BTN disbursed housing loans amounting to 124.927 trillion rupiahs. Meanwhile, the non-housing loan portion is only 10.10 percent or 14.029 trillion rupiahs in 2015.

Even though BBTN has more housing loan portion than a non-housing loan, BTN gets supported by the government. In 2011, Fitch Ratings upgraded the long-term national rating of BBTN to 'AA (idn)' from 'AA- (idn)' with a stable outlook. The rating agency believes that the government will support BTN if necessary even in limits on state financial capacity as well as the systemic influence of BTN compared to other government banks (Nurfuadah, 2011). Even though BBTN in 2011 had PD 47.57 percent, BBTN able to decrease their PD to be 8.59 percent in 2012 .

Table 16. PD for banks with $1^{\text {st }}$ category

\begin{tabular}{lrrrrrrrr}
\hline & \multicolumn{9}{c}{ Probability of Default (\%) } \\
\cline { 2 - 8 } & $\mathbf{2 0 1 0}$ & $\mathbf{2 0 1 1}$ & $\mathbf{2 0 1 2}$ & $\mathbf{2 0 1 3}$ & $\mathbf{2 0 1 4}$ & $\mathbf{2 0 1 5}$ & Average & SD \\
\hline BMRI & 0.02 & 0.10 & 0.13 & 0.22 & 0.01 & 0.01 & 0.08 & 0.09 \\
BBRI & 2.30 & 0.53 & 0.44 & 0.52 & 0.47 & 0.27 & 0.75 \\
BBNI & 0.19 & 1.54 & 1.55 & 3.65 & 0.09 & 3.12 & 1.69 & 1.77 \\
BBTN & 3.64 & 47.57 & 8.59 & 13.71 & 4.51 & 11.71 & 14.96 & 16.45 \\
\hline
\end{tabular}

Table 17. PD for banks with $2^{\text {nd }}$ category

\begin{tabular}{|c|c|c|c|c|c|c|c|c|}
\hline \multirow{2}{*}{ Code } & \multicolumn{8}{|c|}{ Probability of Default (\%) } \\
\hline & 2010 & 2011 & 2012 & 2013 & 2014 & 2015 & Average & SD \\
\hline AGRO & 3.93 & 13.55 & 25.08 & 14.67 & 15.22 & 6.19 & 13.10 & 7.52 \\
\hline BABP & 19.89 & 11.46 & 20.15 & 17.39 & 35.65 & 9.37 & 18.98 & 9.29 \\
\hline BBCA & 0.01 & 0.00 & 0.00 & 0.01 & 0.00 & 0.00 & 0.00 & 0.01 \\
\hline BBKP & 21.00 & 15.47 & 12.23 & 11.71 & 7.98 & 16.28 & 14.11 & 4.49 \\
\hline BDMN & 0.25 & 0.15 & 0.91 & 1.96 & 0.01 & 1.42 & 0.78 & 0.79 \\
\hline BNBA & 22.45 & 15.41 & 11.35 & 16.18 & 22.04 & 16.97 & 17.40 & 4.22 \\
\hline BNGA & 1.17 & 0.80 & 0.63 & 7.91 & 0.32 & 2.01 & 2.14 & 2.89 \\
\hline BNII & 0.32 & 2.32 & 3.08 & 4.98 & 0.32 & 1.84 & 2.14 & 1.77 \\
\hline BNLI & 1.46 & 14.05 & 18.32 & 18.19 & 7.03 & 19.85 & 13.15 & 7.37 \\
\hline BSWD & 0.00 & 1.88 & 0.62 & 16.19 & 29.37 & 7.16 & 9.20 & 11.59 \\
\hline INPC & 7.26 & 32.95 & 5.91 & 0.06 & 5.20 & 3.66 & 9.17 & 11.91 \\
\hline MAYA & 0.35 & 3.85 & 1.99 & 6.48 & 16.89 & 7.81 & 6.23 & 5.91 \\
\hline MEGA & 11.01 & 8.23 & 2.08 & 21.34 & 4.39 & 0.08 & 7.86 & 7.72 \\
\hline NISP & 7.99 & 14.32 & 6.42 & 4.68 & 7.19 & 11.20 & 8.63 & 3.52 \\
\hline PNBN & 11.24 & 11.36 & 13.43 & 14.75 & 0.19 & 2.86 & 8.97 & 5.98 \\
\hline SDRA & 4.45 & 4.83 & 18.02 & 1.01 & 29.69 & 6.61 & 10.77 & 10.94 \\
\hline
\end{tabular}




\subsection{Probability of Default description analysis for $2^{\text {nd }}$ category}

A default probability is the degree of likelihood that the borrower of a loan or debt will not be able to make the necessary scheduled repayments. Table 17 shows assets that owned by 4 categories of banks

Based on Table 17, it shows that banks with the highest PD are BABP with 35.65 percent in 2014. BABP in 2013 had worse performance. It could be explained that NPL from BABP from 2011 to 2012 was above 5 percent, 6.25 percent in 2011 and 5.78 percent in 2012. This condition was still consistent in 2014, its NPL 5.88 percent. Furthermore, OEOI from BABP in 2011 was 114.63 percent, 107.77 percent in 2013 and 108.54 percent in 2014. Other worse performance from BABP can be explained by ROA and ROE. ROA from BABP in 2011 was -1.64 percent, it was the lowest ROA of other banks. In 20142015, BABP also had negative ROA. They were 0.93 percent in 2014 and -0.83 percent in 2015. ROE from BABP in 2011 was -18.96 percent, it was the lowest ROE of other banks. In 2014-2015, BABP also had negative ROE. They were -16.28percent in 2014 and -6.69 percent in 2015.

Because of this performance, MNC Group through MNC Kapital Indonesia has acquired 54.86 million shares of PT Bank ICB Bumiputera Tbk (BABP). The purchase price of these shares reached 7.95 billion rupiahs. Thus, MNC Kapital Indonesia pocketed 1.37 billion shares, equivalent to 25 percent ownership of ICB Bumiputera. MNC Capital previously purchased 1.316 million shares of Bank ICB Bumiputera and ICB Financial Group Holdings AG to 24 percent ownership of ICB Bumiputera shares. The transaction was made on January 27, 2014. The purchase of shares by MNC Kapital Indonesia was done at 160 rupiahs per share price. On October 15, 2014, PT Bank ICB Bumiputera Tbk officially changed its name to PT Bank MNC Internasional Tbk (Mas Sari, 2014).
It's different from BSWD, this bank also had a high probability of default with 29.37 percent in 2014. It is consistent with BSWD's financial condition. In 2015, BSWD had NPL above 5 percent that is equal to 8.9 percent. OEOI from BSWD above 100 percent in 2014-2015 those equal to 235.20 percent in 2014 and 110.20 percent in 2015. BSWD also have negative ratios from ROE value with -4.50 percent in 2014 and have a negative ratio from ROA value with -0.83 percent in 2015.

Although, BSWD had a high probability of default BSWD still exists. In the first half of 2014, BSWD's net profit slumped 20.11 percent because this bank had frisk interest expenses. Although credit grew 26.38 percent year on year from 2.83 trillion rupiahs in June 2014 to 3.57 trillion rupiahs, which impacted BSWD's interest income, it increases 45.73 percent from 197.25 billion rupiahs in June 2014 to the position of 287.47 billion rupiahs. However, the interest expense incurred by BSWD is higher than interest income from credit. The decline in net income was also contributed by skyrocketing loss in value of financial assets in the amount of 267.79 percent from 29.99 billion rupiahs in June 2014 to be 8.15 billion rupiahs in the same month this year (Helen, 2015). Therefore, BSWD preferring to adopt a conservative strategy by budgeting high reserves and making internal improvements, to absorb various potential increases in pressure on asset quality. Meanwhile, the company's strategy prioritizes increasing the reserve coverage ratio to above 100percent.

In addition, BSWD also directly carried out substitution actions relating to non-performing loans in the mining and export sectors with micro, small and medium enterprises (MSMEs). BSWD's targets, at least as much as 20 percent of the total BSWD's loan portfolio is dominated by loans from MSMEs entrepreneurs. This strategy was then followed by BSWD's action to carry out a rights issue on Dec. 2014 (Helen, 2015). The planned use of funds obtained by a rights issue will be used entirely to 
strengthen the capital structure and increase productive assets in the form of credit distribution. It was proven that 100percent of the proceeds from the rights issue in 2014 was absorbed. This means that the market is still trusted BSWD about its future performance.

However, 6 banks (AGRO, BBKP, BNBA, INPC, MEGA, and SDRA) ever have PD's score above 20 percent, their financial performance is not indicated default condition. Furthermore, there is no action following from those conditions. It can be concluded that the Merton model does not represent the real situation from the probability of default absolutely.

\section{Probability of Default description analysis for the $3^{\text {rd }}$ category}

A default probability is the degree of likelihood that the borrower of a loan or debt will not be able to make the necessary scheduled repayments. Table 18 shows assets that owned by 4 categories of banks

Based on Table 18, it shows that banks with the highest PD in bank category 3 are BVIC. Even though BVIC has a high score of the probability of default, their performances (NPL, OEOI, ROA, and ROE) are good.

It can be concluded that the probability of default from the Merton model (1974) is not an abso- lute measure that describes the bank's default in providing credit. The probability of bank failure is an estimate of the probability of default value of a bank based on a market assessment of the bank on how the condition of the bank's assets and liabilities.

\section{Probability of Default description analysis for $4^{\text {th }}$ category}

A default probability is the degree of likelihood that the borrower of a loan or debt will not be able to make the necessary scheduled repayments. Table 19 shows assets that owned by 4 categories of banks.

Based on Table 19, it shows that BACA and MCOR have high PD (above 20\%). It is equal with the result before. Though BACA and BVIC have a high score of the probability of default, their performances (NPL, OEOI, ROA, and ROE) are good. It can be concluded that the use of the Merton model requires prudence and further analysis, requiring a more in-depth examination to examine the corporate action of the company concerned.

\section{Probability of Default description analysis for BUKU category}

In addition, this study using 4 categories of commercial banks, it also uses the BUKU category

Table 18. Probability of Default for banks with $3^{\text {rd }}$ category

\begin{tabular}{lrrrrrrrr}
\hline & \multicolumn{7}{c}{ Probability of Default (\%) } \\
\cline { 2 - 9 } & $\mathbf{2 0 1 0}$ & $\mathbf{2 0 1 1}$ & $\mathbf{2 0 1 2}$ & $\mathbf{2 0 1 3}$ & $\mathbf{2 0 1 4}$ & $\mathbf{2 0 1 5}$ & Average & SD \\
\hline BTPN & 0.94 & 0.21 & 0.00 & 0.05 & 0.00 & 0.13 & 0.22 & 0.36 \\
BVIC & 38.56 & 36.21 & 25.85 & 36.21 & 13.85 & 36.37 & 31.17 & 9.60 \\
\hline
\end{tabular}

Table 19. Probability of Default for Banks with $4^{\text {th }}$ Category

\begin{tabular}{llllrrrrr}
\hline \multirow{2}{*}{ Code } & \multicolumn{8}{c}{ Probability of Default (\%) } \\
\cline { 2 - 8 } & $\mathbf{2 0 1 0}$ & $\mathbf{2 0 1 1}$ & $\mathbf{2 0 1 2}$ & $\mathbf{2 0 1 3}$ & $\mathbf{2 0 1 4}$ & $\mathbf{2 0 1 5}$ & Average & SD \\
\hline BACA & 12.51 & 15.00 & 21.83 & 25.95 & 35.38 & 13.66 & 20.72 & 8.87 \\
MCOR & 41.28 & 44.67 & 36.92 & 37.87 & 28.23 & 5.75 & 32.45 & 14.20 \\
\hline
\end{tabular}




\section{Jurnal Keuangan dan Perbankan \\ Volume 23, Issue 2, April 2019: 283-299}

to explain the relationship between PD value and the bank's real financial condition. The following is a table that shows a summary of PD values based on the BUKU category.

Similar to PD analysis with bank financial performance based on the previous 4 categories of commercial banks, analysis based on BUKU categories have the same conclusion. Sequentially based on the BUKU category which has the largest to the smallest PD values are banks in BUKU 1, banks in BUKU 2, banks in BUKU 3, and banks in BUKU 4. Banks in BUKU 1 even though it has the largest PD average value of 20.10 percent, but in the average financial performance of banks in this category tends to be good. This can be seen from the average value of assets is 6,658.38 billion rupiahs, debt is 5,872.04 billion rupiahs, Liabilities to Assets is 87.85 percent, NPL is 2.45 percent, OEOI is 96.62 percent, ROA is 1.58 percent and ROE 9.89 percent. Similarly, banks in BUKU 2 have a PD average of 14.81 percent, but on average the financial performance of BUKU 2 banks also tends to be good. The good financial performance of banks in BUKU 2 could be seen from the asset value of $19,340.51$ billion rupiah, debt $17,118.29$ billion rupiahs, Liabilities to Assets is 87.40 percent, NPL is 2.14 percent, OEOI is 86.26 percent, ROA is 1.46 percent and ROE is 11.90 percent.

It can be concluded that the Merton model in the analysis based on the BUKU category is consistent for banks in BUKU 4 only. The bank's PD value in this category is the smallest, which is 0.66 percent, which is also consistent with good financial conditions. Banks that are included in BUKU 4 banks are BMRI, BBRI, BBCA, and BBNI. Individually, the $P D$ values for these banks are between 0.00 per- cent -3.65 percent and individually, the financial performance also tends to be good and even better than banks from others. In contrast to banks in BUKU 3 which have an average PD value of 6.46 percent and have better financial performance compared to BUKU 1 and BUKU 2, but individually there are still some banks that have PD between 11.7121.34 percent.

\section{Discussion}

Merton model has been perceived as a forward-looking model that could predict probability of default Yusof \& Jaffar (2017). Probability of default with KMV Merton used to estimate the likelihood of a company experiencing default when the obligation is due. KMV Merton also estimates how far the distance between the value of the company's assets and the point of default. From 4 banks categories, only BABP that consistent with financial condition. Its contrasts with BBTN, AGRO, BBKP, BNBA, INPC, MEGA, SDRA, BVIC, BACA and MCOR. Even though they have high PD value, their financial condition is still normal and no event following from that condition. Related with analysis based on the BUKU categories, the Merton model is consistent for banks in BUKU 4 only. Even though banks in BUKU 1 have the largest PD but in the average, the financial performance of banks in this category tends to be good.

The failure of the Merton model in predicting default risk might be because the equity price in KMV-Merton model is only assessed using fundamental value. In this context, equity value is determined by the net worth of the firm, so the factors

Table 20. Probability of Default for banks with BUKU category

\begin{tabular}{ccccc}
\hline \multirow{2}{*}{ BUKU Category } & \multicolumn{4}{c}{ Probability of Default (\%) } \\
\cline { 2 - 5 } & Average & Min & Max & SD \\
\hline 1 & 20.10 & 0.62 & 37.87 & 10.73 \\
2 & 14.81 & 0.06 & 36.37 & 11.66 \\
3 & 6.46 & 0.00 & 21.34 & 6.50 \\
4 & 0.66 & 0.00 & 3.65 & 1.14 \\
\hline
\end{tabular}


reviewed by Merton are only uncertainties about the company's net asset value (firm-specific risk). Merton assumes market movements do not cause investors to overvalue or undervalue the price of a stock, so the equity price simply refers to its fundamental value.

Majumder (2006), gives a critique of Merton's model, which states that the Merton model applies if the market is always in an efficient condition. However, in reality, the market is not always efficient, the equity price is not only influenced by specific firms, but also the equity price is the result of a combination of firm-specific and market-related factors. This is thought to be the cause of the failure of the Merton model in assessing default risk when the market becomes inefficient. It cannot be denied that the factor of investor behavior in the form of market sentiment also affects market movements. This finding can be explained by the argument that the probability of bank failure with the Merton model needs more in-depth analysis, it is possible to modify the Merton model to be more accurate by considering the weaknesses of the model.

\section{Conclusion, Limitation, and Suggestions Conclusion}

As the conclusion, the probability of default with the Merton model gives a strong signal against the default of bank for one bank only. The bank that has a high probability of default and parallel with the financial condition is BABP. Even though the probability of default from BBTN, AGRO, BBKP, BNBA, INPC, MEGA, SDRA, BVIC, BACA and MCOR have high but the real condition is normal. There is no information found in these banks which indicates to default. Merton model also gives a strong signal against the default of banks in BUKU 4 only. For banks in BUKU 1, and banks in BUKU 2 which have high PD value but on average the financial condition tends to be good. Furthermore, banks in BUKU 3 although have low PD value and financial condition is consistent good but individually there are some banks that have high PD value. Thus, the Merton model is not an absolute measure that describes the bank default since the failure of the Merton model in predicting default risk. This might be attributed to the fact that the equity price in KMVMerton model is only assessed using fundamental value and market assumption as an efficient condition. Majumder (2006) stated Merton's model presumes that the market is efficient and equity price is governed only by its fundamental value. Merton's model misinterprets the basic nature of financial markets. The Merton model needs more studied to improve the Merton model as the probability of default predictor. Basically, the desired default risk prediction model in banking practice is a simple, predictable, transparent, stable and easy to implement computerized, the model can look forward, not only representatives of the past and can handle very large data.

\section{Limitation and suggestions}

This study compares the default risk measured by KMV Merton model with real bank conditions based on the PD value. This study did not test the validity of the Merton model statistically for example by using the Cumulative Accuracy Profile (CAP) curve and the Receiver Operating Characteristic (ROC) (Camara, Popova, \& Simkins, 2011). Because there is a criticism of the KMV-Merton Model, further research is suggested to use the revision model from Majumder (2006) which perfecting the limitations of the Merton (1974) model by using a company's equity as a linear combination of the effects of endogenous factors and exogenous factors. 


\section{References}

Altman, E. I. (1968). Financial ratios, Discriminant Analysis, and the prediction of corporate bankruptcy. Journal of Finance, 23(4), 589-609. https://doi.org/10.1111/j.1540-6261.1968.tb00843.x

Acharya, V. V., Deniz, A., \& Warburton, A. J. (2016). The end of market discipline? Investor expectations of implicit state guarantees. http://dx.doi.org/10.2139/ssrn.1961656

Bellalah, M., Zouari, S., \& Levyne, O. (2016). The performance of hybrid models in the assessment of default risk. Economic Modelling, 52, 259-265. https://doi.org/10.1016/j.econmod.2014.10.051

Black, F, \& Scholes, M. (1973). The pricing of options and corporate liabilities. The Journal of Political Economy, 81(3), 637-654. http://dx.doi.org/10.1086/260062

Camara, A., Popova, I., \& Simkins, B. (2011). A comparative study of the probability of default for global financial firms. Journal of Banking and Finance, 36, 717-732. https://doi.org/10.1016/j.jbankfin.2011.02.019

Das, S. R., Hanouna, P., \& Sarin, A. (2009). Accounting-based versus market-based cross-sectional models of CDS spreads. Journal of Banking and Finance, 33, 719-730. https://doi.org/10.1016/j.jbankfin.2008.11.003

Duan, J., \& Ren, S. (2011). Assessing the default risk of chinese public companies in the energy industry. Thesis. Master Programme. Lunds University, Swedish.

Helen, D. (2015). Kinerja Semester I/2015: Laba Bank of India Indonesia Terkoreksi 20,11\%. Retrieved from: https://finansial.bisnis.com/read/20150807/90/460334/kinerja-semester-i2015-laba-bank-of-india-indonesia-terkoreksi-2011.

Li, M.-Y. L., \& Miu, P. (2010). A hybrid bankruptcy prediction model with dynamic loadings on accounting-ratio-based and market-based information: A binary quantile regression approach. Journal of Empirical Finance, 17(4), 818-833. https://doi.org/10.1016/j.jempfin.2010.04.004

Jones, S., Johnstone, D., \& Roy Wilson. (2015). An empirical evaluation of the performance of binary classifiers in the prediction of credit ratings changes. Journal of Banking and Finance, 56, 72-85. https://doi.org/10.1016/j.jbankfin.2015.02.006

Jones, S., Johnstone, D., \& Wilson, R. (2017). Predicting corporate bankruptcy: An evaluation of alternative statistical frameworks. Journal of Business Finance and Accounting, 44(1-2), 3-34. https://doi.org/10.1111/jbfa.12218

Jorion, P. (2009). Financial Risk Manager Handbook. 5th Edition. Published by John Wiley and Sons, Inc.

Kleinert, M. K. (2014). Comparison of bankruptcy prediction models of Altman (1969), Ohlson (1980) and Zmijewski (1984) on German and Belgian listed companies between 2008-2013. Thesis. Master Programme. University of Twente, Netherlands

Liang, X. (2012). An empirical estimation of the default risk of chinese listed company based on the Merton-KMV Model. Thesis. Norwegian School of Economics

Löffler, G., Posch, P. N. (2011). Credit Risk Modelling using Excel and VBA. Published by John Wiley \& Sons Inc.

Majumder, D. (2006). Inefficient markets and credit risk modeling: Why Merton's Model failed. Journal of Policy Modeling, 28(3), 307-318. https://doi.org/10.1016/j.jpolmod.2005.10.006

Mansi, S. A., Maxwell, W. F., \& Zhang, A. (2012). Bankruptcy prediction models and the cost of debt. The Journal of Fixed Income 21(4), 25-42. https://doi.org/10.3905/jfi.2012.21.4.025

Mas Sari, S. (2014). Dikuasi Hary Tanoe, ICB Bumiputera resmi menjadi Bank MNC. Retrieved from: http://finansial.bisnis.com/read/20141025/90/267758/dikuasai-hary-tanoe-icb-bumiputera-resmi-menjadi-bank-mnc. October 25, 2014. 


\title{
Probability of default as the early warning system for the Indonesian banking sector
}

\author{
Ari Christianti
}

Merton, R. C. (1974). On the pricing of corporate debt: The risk structure of interest rates, Journal of Finance, 29(2), 449-470. https://doi.org/10.1111/j.1540-6261.1974.tb03058.x

Nurfuadah, R. N. (2011). Fitch naikkan peringkat BTN ke 'AA(idn)'. Retrieved from: https:/economy.okezone.com/read/2011/10/27/278/521125/fitch-naikkan-peringkat-btn-ke-aa-idn. October 27, 2011

Ohlson, J. (1980). Financial ratios and the probabilistic prediction of bankruptcy. Journal of Accounting Research, 18(1), 109-131. https://doi.org/10.2307/2490395

Rim, E. K., \& Roy, A B. (2014). Classifying manufacturing firms in Lebanon: An application of Altman's model. Procedia-Social and Behavioral Sciences, 109, 11-18. https://doi.org/10.1016/j.sbspro.2013.12.413

Sun, J., Li, H., Huang, Q-H., \& He, K-Y. (2014). Predicting financial distress and corporate failure: A review from the state-of-the-art definitions, modeling, sampling, and featuring approaches. Knowledge-Based Systems, 57, 4156 https://doi.org/10.1016/j.knosys.2013.12.006

Tanthanongsakkun, S., Pitt, D., \& Treepongkaruna, S. (2009). A Comparison of corporate bankruptcy models in Australia: the Merton vs Accounting-based models. Asia-Pacific Journal of Risk And Insurance, 3, 93-112. https://doi.org/10.2202/2153-3792.1042

Tsesmelidakis, Z. \& Merton, R. C. (2013). The value of implicit guarantees. Working Paper. MIT Working

Wu, Y., Gaunt, C., \& Gray, S. F. (2010). A comparison of alternative bankruptcy prediction models. Journal of Contemporary Accounting and Economics, 6, 34-45 https://doi.org/10.1016/j.jcae.2010.04.002

Yeh, C.-C., Lin, F., \& Hsu, C.-Y. (2012). A hybrid KMV model, random forests and rough set theory approach for credit rating. Knowledge-Based Systems, 33, 166-172. https://doi.org/10.1016/j.knosys.2012.04.004

Yusof, N. M., \& Jaffar, M. M (2017). KMV-Merton Model-Based forecasting of default probabilities: A case study of Malaysian Airline System Berhad. Journal of Engineering and Applied Sciences, 12, 4297-4300.

Zmijewski, M. E. (1984). Methodological issues related to the estimation of financial distress prediction models. Journal of Accounting Research, 22, 59-82. http://dx.doi.org/10.2307/2490859 